https://doi.org/10.15407/ufm.19.02.185

PACS numbers: 61.72.sh, 64.70.dg, 66.30.Fq, 68.35.Ja, 68.70.+w, 81.10.Aj, 81.10.Jt, 81.40.Ef

\author{
O.V. MOVCHAN and K.O. CHORNOIVANENKO \\ National Metallurgical Academy of Ukraine, \\ 4 Gagarin Ave., \\ UA-49600 Dnipro, Ukraine
}

\title{
THE ANALYSIS OF MORPHOLOGICAL STABILITY OF A RECRYSTALLIZATION FRONT
}

\begin{abstract}
A generalization of theoretical information about the patterns of trans-formation of a conversion front during phase reactions is carried out. The theory of concentration supercooling based on diffusional redistribution of alloy components in a melt near crystallization boundary is considered. Transformation mechanisms of flat front of crystallization with structure change into cellular and dendritic are studied. Regulations of the interfacial boundary instability during the phase transition are considered. The effect of alloying elements on the morphology of the transformation front is analysed. The conditions of the morphological stability of the recrystallization front in the high-alloyed iron alloys during chemical-thermal treatment are considered. As established, the transformation of the conversion front is carried out under the action of concentration gradients. This is caused by the redistribution of the base alloying elements ahead of the recrystallization front.
\end{abstract}

Keywords: recrystallization front, phase transformations, front transformation, interphase boundary, concentration gradients, chemical-thermal treatment.

\section{Analysis of the Theory for Transformation of a Phase Conversion Front}

The profile of the transformation front is an important characteristic of the crystal growth process and depends on the thermophysical conditions at the front, concentration of the alloying elements and impurities. Transformation of the flat transformation front into cellular and then into dendritic is one of the most fundamental and important solidification phenomena [1,2], which determines the structural perfection of a material.

Regularities of morphology change of the crystallization front at slow velocities of the front motion $\left(\sim 10^{-7}-10^{-4} \mathrm{~m} / \mathrm{s}\right)$ have been inten- 
sively studied since the early 1950 s by W. Tiller, B. Chalmers, J. Ruter. They created a theory of concentration supercooling based on concepts of diffusion redistribution of alloy components in a melt near meltcrystal interface [3]. This theory was later developed within the linear stability model of Mullins and Sekerka [4, 5], and by Coriell and Sekerka [6-8] that was later generalized to the nonlinear domain by Davis [9]. The authors have established that the cellular structure of the interphase boundary arises in the case when the interphase surface becomes unstable to wave distortions. This model was developed for flat and spherical cases, as well as for the formation of a cellular front in the process of directional crystallization, which determines the segregation of impurities and dislocation structure of the crystal. As shown latter, the cellular structure in binary alloys could be formed due to the convective mechanism of heat and mass transfer near this boundary at low crystallization rates [10]. The mass transfer is thermogravitation convection at the melt-crystal interface. The paper [10] made it clear under what control parameters a cellular front is formed, both under convection conditions at the melt-crystal interface and without it. Trivedi and Kurz [11-13] extended the Mullins-Sekerka model for high velocities of boundary movement $\left(\sim 10^{-3} \mathrm{~m} / \mathrm{s}\right)$ and higher without going beyond the heat-diffusion mechanism for the redistribution of components of the binary alloy near the melt-crystal interface. The theory of Mullins and Sekerka was confirmed in many experimental works and numerical decision of the corresponding diffusion problem (see, for example, Refs. [14-20]).

The cellular structure was studied at high drawing velocities in [21]. It was shown that the solidifying surface becomes flat when the certain high speed value is reached: $\sim 3 \cdot 10^{4} V_{c}$ for the succinonitrile-argon system (here, $V_{c}$ denotes a critical solidification velocity). Such flat front rebuilding was predicted as a particular consequence of a linear analysis of the stability of Mullins and Sekerka [4] and is called absolute stability. For a better understanding of this phenomenon, it is necessary to model directional solidification at an atomic scale, which was done in Ref. [22]. The kinetic modelling of directional solidification on an atomic scale was performed by the Monte Carlo method for the lattice liquid model. The presence of vacancies in the melt, which contributes to the components diffuse, was taken into account.

The authors of Ref. [23] give an analysis of linear morphological stability for the full range of crystallization rates: from low velocities in the diffusion-limited regime to ultra-high velocities of the front movement, when a diffusionless (chemically non-selective) regime is performed.

It was shown in [24] that the growth of a two-phase zone as the heterojunction zone from crystal to melt during crystallization of met- 
als and alloys is due to the reaction of the system to supercooling for the fastest transition to a quasi-equilibrium state. Intensive deposition of atoms at the interface between the liquid and solid phases leads to a rapid decrease in the supercooling at the interface. The emergence of a macrorough boundary of the cellular-dendritic structure is necessary to isolate a large amount of latent heat of crystallization [25]. The determining role in the appearance of such cellular-dendrite forms has the established balance between the force morphologically destabilizing the front (proportional to gradient of the impurity-element concentration) and the force stabilizing the front (proportional to the surface energy of crystal-liquid interface). The morphological (in)stability of the initial solidification front is reached, if one of the forces prevails. Therefore, the growth of the two-phase zone passes through the stage of the morphological instability of the microrough front to the appearance of stable macroscopic branched forms of the cellular-dendrite structure.

The paper [26] describes the multiphase model for predicting cellular-dendrite transformation during solidification of binary alloys. A mechanism of cellular structure formation associated with the occurrence of dislocations along the grain boundaries is known, for instance, in the case when metals are irradiated with pulsed electron streams and subsequent deformation [27]. The paper [28] is devoted to the study of formation of cellular structures from a melt in binary systems. It has been experimentally proved that there is the mechanism for the formation of a cellular structure associated with concentration supercooling (diffusional redistribution of the alloy components at the melt-crystal interface) in addition to the dislocation mechanism. The surface tension anisotropy and growth kinetics also influence on cells formation during directional crystallization [29].

According to the results of a theoretical analysis in [30], a mathematical model of the process of structure change of metal alloys was developed. The model was created for $\mathrm{Fe}-0.5 \% \mathrm{C}$ alloy in the surface layer of the order of several microns. The diffusion processes of redistribution of components at the interface were taken into account.

The authors of Ref. [31] obtained experimental results, which allow showing a close relationship between kinetics and morphology development of dendritic structure in the studied alloys with the magnitude of diffusion supercooling in the two-phase zone. At the same time, these results show that cellular model of the two-phase zone reflects correctly a nature of diffusion (liquation) processes determining the evolution of dendrite structure in the elementary volume of the two-phase zone.

A physical model of convective heat and mass transfer in a melt near the crystallization front has been developed in [32, 33] due to the thermocapillary and concentration-capillary mechanisms acting on the melt-crystal interface. 
The authors of Ref. [34] obtained criteria for the formation of columnar and equiaxial grains by the process of dendritic crystallization. It is shown that natural convection in a melt reduces local temperature gradients. Thus, the convection extends a supercooling zone ahead of the crystallization front and leads to increasing the potential for the growth of equiaxial grains.

A fundamental problem in the process of formation of eutectic structures is the question of a nature of morphological instability of the simplest spatially periodic stationary states that lead to such a diverse dynamics [35]. The variety of shapes and sizes of the resulting phase structures is determined by nonequilibrium processes near a boundary of the phase transition. Article [36] gives a comprehensive review of the current state of solidification studies. Authors [36] consider the stability of the interface during formation of three-dimensional dendrite structures by directed growth of a dendrite vertex and the formation of lateral branches, the stability of the interphase boundary in cellular crystallization, as well as a morphological instability and the oscillation of the interphase boundary during formation of eutectic structures. The most popular theory that describes the process of crystallization of eutectic melts with formation of periodic structures is the Jackson-Hunt theory [37]. However, it does not explain the reasons of periodic structures formation, and it cannot overcome difficulties in selecting the decision of considered equations.

Many researchers believe that the main reason for appearance of periodic structures is instability of the interphase boundary in the process of phase transition. There are many theoretical calculations that give qualitative correspondences of one or another mathematical model of directional crystallization with observable structures since the classical paper [4].

As a rule, the presence of alloying elements leads to changes in macro- and microstructures of a eutectic and to appearance of fan-like structures that called colonial ones. As firstly shown by Weart and Mack [38], the appearance of fan-shaped colonial structures is associated with the curvature of flat crystallization front and its transformation into a cellular one. The appearance of the cellular front during single-phase solidification of binary alloys is due to a redistribution of alloying elements between the phases.

Boiling and Tiller [39] attempted to relate size of the cells to velocity of the crystallization front on basis of the diffusion equation decision. However, it was not possible to achieve a good correspondence with the experimental data. The authors explained this by a great sensitivity of the calculated data to initial assumptions. The more advanced models have been built using numerical methods by now. If thermodynamic equilibrium was assumed in [39] at the interphase boundary, the 
authors of [40] constructed a nonequilibrium model of cellular structure growth. The same authors [41] used combined numerical methods to provide the required level of accuracy. The authors of [42] obtained a good agreement with their own experimental data in $\mathrm{Al}-4.5 \% \mathrm{Cu}$ system. They took into account diffusion in the solid phase and convective flow.

The authors of Refs. [43, 44] observed the phenomenon of flat front transformation into cellular front at $\alpha \rightarrow \gamma$-recrystallization of carburized Fe-Si alloys. The effect of concentration supersaturation of ferrite by carbon explained that. It was analogous to concentration supercooling during crystallization of alloys.

The above-mentioned works mainly deal with the crystallization of melts. There are no enough publications devoted to transformation of the flat conversion front during the recrystallization [45]. That is why an additional research is needed.

\section{Formation of a Recrystallization Front in High-Alloyed Iron Alloys during Decarburization}

The transformation of recrystallization front into cellular and transformation of columnar ferrite grains into branched dendrites is observed during decarburization of the experimental alloy $\mathrm{T} 1$ with $\sim 2 \%$ of carbon by mass (Fig. 1). Decarburization of the investigated alloy was carried out for 1.5 hours at $1050^{\circ} \mathrm{C}$ in the first stage and 2 hours at $1200^{\circ} \mathrm{C}$ in the second stage in a wet hydrogen atmosphere in laboratory installation. Analysis of the isothermal section of $\mathrm{Fe}-\mathrm{W}-\mathrm{C}$ phase diagram at the processing temperature (Fig. 2) suggested that the cause of $\alpha \rightarrow \gamma$ front instability relates to the interphase redistribution of the basic alloying element (tungsten) in accordance with the equilibrium conditions. Diffusion ferritization of surface layer in the investigated alloys is accom-

Fig. 1. Recrystallization front during decarburization of the experimental $\mathrm{T} 1+2 \% \mathrm{C}$ alloy (scaling $\times 50$ )

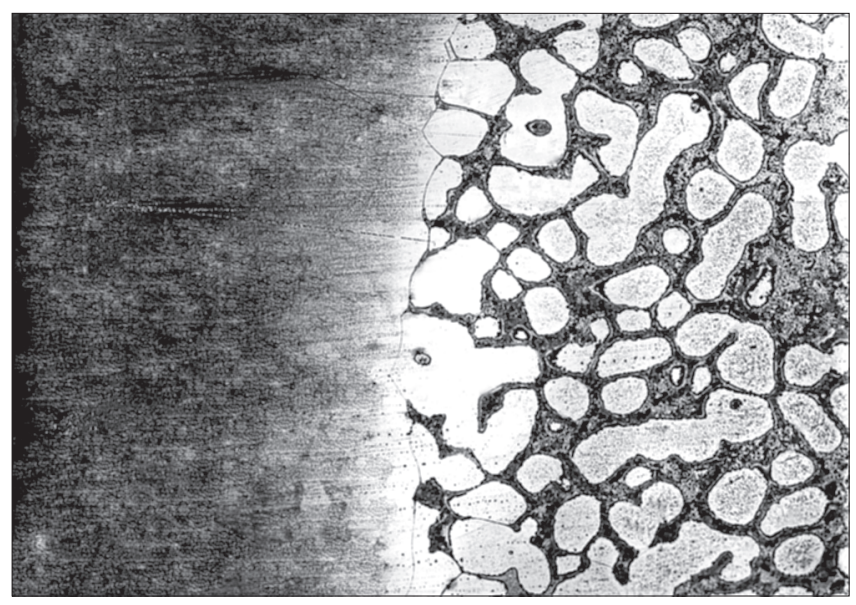




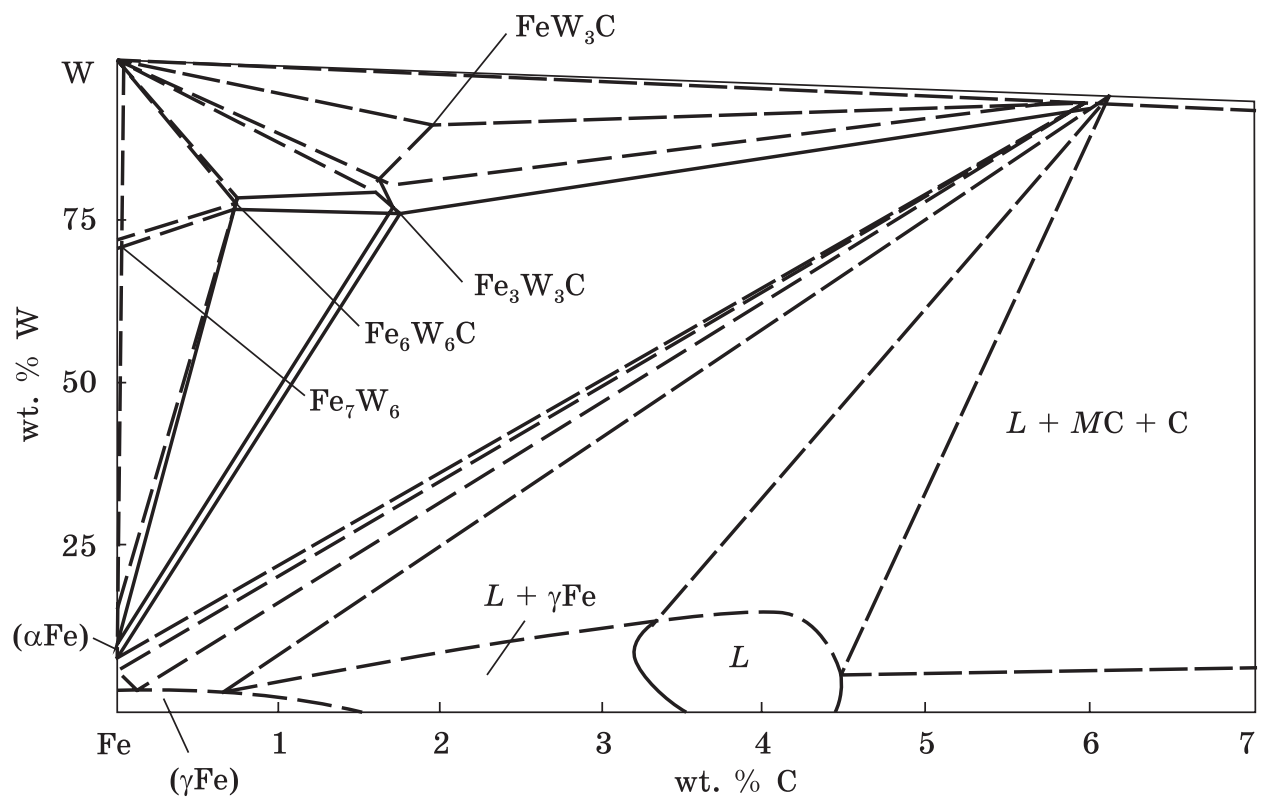

Fig. 2. Chart of the isothermal cross-section for $\mathrm{Fe}-\mathrm{W}-\mathrm{C}$ ternary state diagram at $1200^{\circ} \mathrm{C}$ [46], where $M$ is a metal and $L$ is a liquid

panied by interphase redistribution of tungsten atoms between the parent phases and the growing $\alpha$-phase. As a result, a chemical inhomogeneity is formed that reflects on the nature of the transition zone structure.

The transformation of recrystallization front is due to various equilibrium concentrations of tungsten at the interphase boundary, primarily in austenite and the growing $\alpha$-phase, as well as in carbide. Tungsten is $\alpha$-stabilizer, so its equilibrium content in the ferrite will be greater than in austenite. Thus, carbon depletion of experimental alloy in the three-phase equilibrium region (ferrite-austenite- $M_{6} \mathrm{C}$ carbide) leads to increasing in the difference between the equilibrium concentrations of tungsten in these phases (Fig. 2). Consequently, $\gamma+M_{6} \mathrm{C} \rightarrow \alpha$-transformation is accompanied by redistribution of tungsten between the phases during decarburization of the alloy.

\section{Formation of a Recrystallization Front in High-Alloyed Iron Alloys during Carburization}

Concentration gradients arising during the three-phase (ferrite-austenite-carbide) transformation process cause diffusion redistribution of the alloying elements ahead of the recrystallization front by diffusion saturation with carbon in the $\mathrm{T} 1+2 \% \mathrm{C}$ alloy. It renders a significant effect on the nature of the formed structures. Concentration supersatu- 
Fig. 3. Microstructure of the diffusion layer of the $\mathrm{T} 1+2 \% \mathrm{C}$ alloy after carburization at $1180^{\circ} \mathrm{C}$ (scaling $\times 250$ )

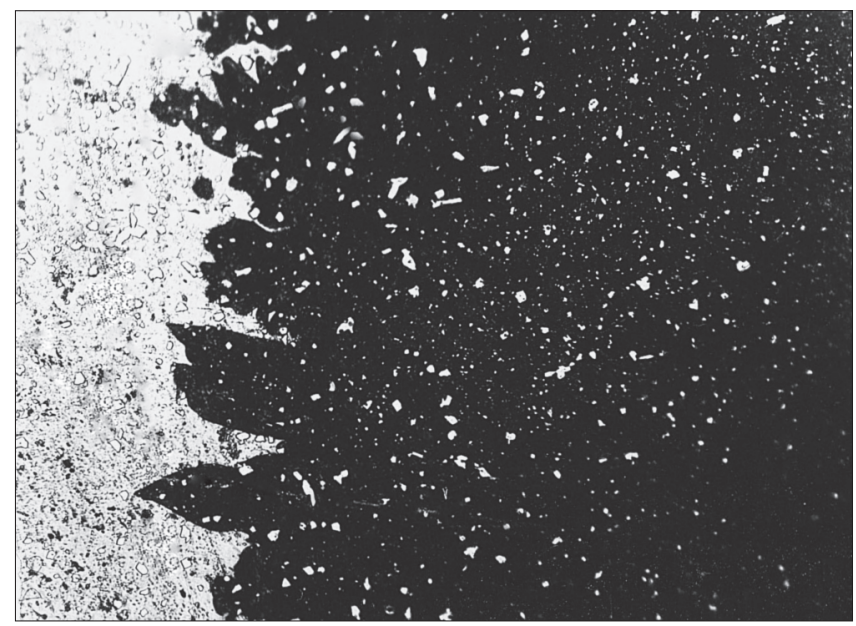

ration zone forms before the conversion front. It is similar to the concentration supercooling during crystallization (first observed by Weart and Mack [38]). The flat $\alpha \rightarrow \gamma$-transformation front turns into a cellular one in the presence of concentration supersaturation zone while losing its stability (Fig. 3). The main alloying element (tungsten) is pushed into the cavities between the protuberances at the front. Random protuberances are formed at the front under more preferable conditions. They germinate into ferrite. Tungsten enriches the cavity by tangential diffusion of it. Herewith, ferrite is even more stabilized.

\section{Conclusions}

Within the framework of this work, we analysed theoretical information dealing with morphological stability of the conversion front during phase reactions. Factors affecting stability of flat front of crystallization and recrystallization are revealed. The transformation of the recrystallization front into cellular and dendritic during chemical-thermal treatment is considered. The concentration gradient of the main alloying element exists ahead the $\gamma \rightarrow \alpha$-transformation front at steady growth of a ferrite layer during the decarburization of iron alloys alloyed by the principle of high-speed steels. This is due to the thermodynamic feature of the isothermal section of the $\mathrm{Fe}-\mathrm{W}-\mathrm{C}$ state diagram. It causes the redistribution of components ahead front of recrystallization. A similar situation is observed in high-alloyed iron alloys during carburizing. The $\alpha \rightarrow \gamma$-flat front of recrystallization turns into a cellular one in case of the presence of a concentration saturation zone, which occurs during the three-phase transformation (ferrite $\rightarrow$ austenite+carbide). In this case, the diffusion change in composition does not lead to a change in content of alloying elements in the alloy. 


\section{REFERENCES}

1. J. Lapin, L. Ondrúљ, and M. Nazmy, Intermetallics, 10, No. 10: 1019 (2002).

2. J. S. Langer and J. Müller-Krumbhaar, J. Crystal Growth, 42: 11 (1977).

3. W. A. Tiller, K. A. Jackson, J. W. Ruter, and B. Chalmers, Acta Met., 1, No. 4: 428 (1953).

4. W.W. Mullins and R.F. Sekerka, J. Appl. Phys., 35, No. 2: 444 (1964).

5. R.F. Sekerka, J. Appl. Phys., 36, No. 1: 264 (1965).

6. S.R. Coriell and R.F. Sekerka, Rapid Solidification Processing II (Eds. R. Mehrabian, B.H. Kear, and M. Cohen) (Baton Rouge, Louisiana: Claitor's: 1980), p. 35.

7. S.R. Coriell, G.B. McFadden, and R.F. Sekerka, Ann. Rev. Mater. Sci., 15: 119 (1985).

8. S.R. Coriell and G.B. McFadden, Handbook of Crystal Growth 1. Fundamentals, Part B: Transport and Stability (Ed. D. T. J. Hurle) (Amsterdam: North-Holland: 1994), p. 785.

9. S.H. Davis, Theory of Solidification (Cambridge: Cambridge University Press: 2001).

10. B. Caroli, C. Caroli, and B. Roulet, J. Physique, 46, No. 3: 401 (1985).

11. R. Trivedi and W. Kurz, Acta Met., 34, No. 8: 1663 (1986).

12. W. Kurz, B. Giovanola, and R. Trivedi, Acta Met., 34, No. 8: 823 (1986).

13. W. Kurz and D. J. Fisher, Fundamentals of Solidification (4th ed.) (Trans Tech Publications: 1998).

14. J. S. Langer, Rev. Mod. Phys., 52, No. 1: 5 (1980).

15. R. A. Brown, Materials Sciences in Space (Eds. B. Feuerbacher, H. Hamacher, and R. J. Naumann) (Berlin-Heidelberg: Springer: 1986), p. 55.

16. D. A. Kessler, J. Koplik, H. Levin, Adv. Physics., 37, No. 3: 255 (1988).

17. J.D. Weeks and W.J. Saarlos, Cryst. Growth, 112: 244 (1991).

18. S. de Cheveigné, C. Guthmann, and M. Lebrun, J. Phys. (Paris), 47: 2095 (1986).

19. B. Billia and R. Triverdi, Handbook of Crystal Growth (Ed. D. Hurle) (Amsterdam: North Holland: 1993), vol. 1(b), p. 899.

20. A.H. Borysov, Kristallografiya, 36: 1267 (1991) (in Russian).

21. A. Ludwig and W. Kurz, Acta Met., 44: 3643 (1996).

22. A.M. Ovrutskiy and M.S. Rasshchupkina, Vestnik Dnepropetrovskogo Universiteta. Seryia 'Fizika. Radioehlektronika', 14, No. 12/1: 85 (2007) (in Russian).

23. D.A. Danilov and P.K. Khalenko, Vestnik Udmurtskogo Universiteta. Fizika. Khimiya, 1: 88 (2008) (in Russian).

24. V.A. Zhuravlyov, Zatverdevanie i Kristallizatsiya Splavov s Geteroperekhodami [Solidification and Crystallization of Alloys with Heterojunctions] (Izhevsk: RHD: 2006) (in Russian).

25. P.K. Galenko and V.A. Zhuravlev, Physics of Dendrites (Singapore: World Scientific: 1994).

26. M.A. Martorano, C. Beckermann, and Ch.-A. Gandin, Metall. Mater. Trans. A, 34, No. 8: 1657 (2003).

27. O.P. Maksimkin, Kh.V. Kadyrov, K.V. Tsai, and N.V. Shcherbinina, Fiz. Met. Metalloved., 97, No. 4: 42 (2004) (in Russian).

28. E. Zielinska-Rohozinska, J. Cryst. Growth., 87: 154 (1988).

29. N.A. Arnautova and A.M. Ovrutskiy, Metallofiz. Noveishie Tekhnol., 21, No. 7: 15 (1999) (in Russian).

30. P.K. Khalenko, E. V. Kharanzhevskiy, and D. A. Danilov, Fiz. Met. Metalloved., 94, No. 2: 100 (2002) (in Russian). 
31. I.I. Sulimtsev, Izvestiya MGTU 'MAMI', 8, No. 2: 54 (2009) (in Russian).

32. H.L. Tsarev, A.P. Laskovnev, and V.B. Babushkin, Vestsi AN BSSR. Seriya Fiz.Tekhn. Navuk, No. 3: 20 (1986) (in Russian).

33. S.A. Astapchik and N.A. Bereza, Fiz. Met. Metalloved., 103, No. 1: 3 (2007) (in Russian).

34. J. Banaszek and D.J. Browne, Mater. Trans., 46, No. 6: 1378 (2005).

35. M. Plapp and A. Karma, Phys. Rev. E, 60, No. 6: 6865 (1999).

36. W.J. Boettinger and S. R. Coriell, Acta Mater., 48: 43 (2000).

37. K.A. Jackson and J.D. Hunt, Trans. Met. Soc. AIME, 236, No. 8: 1129 (1966).

38. H.W. Weart and J.D. Mack, Trans Met. Soc. AIME, 212, No. 3: 664 (1958).

39. G.F. Boiling and W.A. Tiller, J. Appl. Phys., 31, No. 11: 2040 (1960).

40. Yu.I. Petukhov and A.I. Beketov, Izv. AN SSSR. Metally, No. 4: 90 (1980) (in Russian).

41. Yu.I. Petukhov, V. I. Poliakova, and L. V. Potaturkina, Izv. AN SSSR. Metally, No. 2: 76 (1986) (in Russian).

42. N.F. Dean, A. Mortensen, and M. C. Flemings, Metall. Mater. Trans. A, 25, No. 10: 2295 (1994).

43. K.P. Bunin, V.I. Movchan, and V.V. Nikiforova, Izv. VUZov. Chernaya Metallurgiya, No. 2: 106 (1977) (in Russian).

44. V.I. Movchan and V.V. Vladimirova, Izv. AN SSSR. Metally, No. 6: 52 (1988) (in Russian).

45. A.V. Movchan, Stroitelstvo, Materialovedenie, Mashinostroenie: Sbornik Nauchnykh Trudov (Dnipropetrovsk: PGASA: 2009), Iss. 48, Pt. 2, p. 3 (in Russian).

46. G.V. Raynor and V.G. Rivlin, Phase Equilibria in Iron Ternary Alloys (London: The Institute of Metals: 1988).

Received May 15, 2018; in final version, May 29, 2018

О.В. Мовчан, К.О. Чорноіваненко

Національна металургійна академія України, просп. Гагаріна, 4, 49600 Дніпро, Україна

\section{АНАЛІЗА МОРФОЛОГІЧНОЇ СТАБІЛЬНОСТИ ФРОНТУ ПЕРЕКРИСТАЛІЗАЦЇ̈}

Виконано узагальнення теоретичної інформації щодо закономірностей перетворення конверсійного фронту при фазових реакціях. Розглянуто теорію концентраційного переохолодження, основою якого є дифузійний перерозподіл компонентів стопу в розтопі поблизу межі кристалізації. Вивчаються механізми трансформації плаского фронту кристалізації та перекристалізації в комірковий i дендритний. Розглянуто питання нестійкости міжфазової межі в процесі фазових перетворень. Проведено аналізу впливу легувальних елементів на морфологію фронту перетворення. Розглянуто умови морфологічної стабільности фронту перекристалізації у високолегованих залізних стопах в процесі хеміко-термічного оброблення. Встановлено, що трансформація фронту перетворення здійснюється під дією концентраційних градієнтів, спричинених перерозподілом основних легувальних елементів попереду фронту перекристалізації.

Ключові слова: фронт перекристалізації, фазові перетворення, трансформація фронту, міжфазова межа, концентраційні градієнти, хеміко-термічне оброблення. 
A.В. Мовчан, E.A. Черноиваненко

Национальная металлургическая академия Украины, просп. Гагарина, 4,

49600 Днепр, Украина

\section{АНАЛИЗ МОРФОЛОГИЧЕСКОЙ СТАБИЛЬНОСТИ ФРОНТА ПЕРЕКРИСТАЛЛИЗАЦИИ}

Выполнено обобщение теоретической информации о закономерностях превращения конверсионного фронта при фазовых реакциях. Рассмотрена теория концентрационного переохлаждения, основой которого является диффузионное перераспределение компонентов сплава в расплаве вблизи границы кристаллизации. Изучены механизмы трансформации плоского фронта кристаллизации и перекристаллизации в ячеистый и дендритный. Рассмотрены вопросы неустойчивости межфазной границы в процессе фазового перехода. Проводится анализ влияния легирующих элементов на морфологию фронта превращения. Рассматриваются условия морфологической стабильности фронта перекристаллизации в высоколегированных железных сплавах в процессе химико-термической обработки. Установлено, что трансформация фронта превращения осуществляется под действием концентрационных градиентов, вызванных перераспределением основных легирующих элементов впереди фронта перекристаллизации.

Ключевые слова: фронт перекристаллизации, фазовые превращения, трансформация фронта, межфазная граница, концентрационные градиенты, химико-термическая обработка. 